\title{
META-ANALISIS: PENGARUH SUBSTITUSI JAGUNG DENGAN BAHAN PAKAL LOKAL TERHADAP KUALITAS KARKAS DAGING BROILER
}

\section{The Effect of Substitution Yellow Corn with Local Feedstuff on the Meat Quality of Broiler: Meta-Analysis}

\author{
Danung Nur Adli ${ }^{1}$ dan Osfar Sjofjan ${ }^{1}$ \\ ${ }^{1}$ Fakultas Peternakan, Universitas Brawijaya \\ Email: danungnuradli1994@gmail.com
}

\begin{abstract}
INTISARI
Tujuan dari penelitian ini adalah untuk mengetahui pengaruh substitusi jagung dengan bahan pakal lokal terhadap kualitas daging broiler menggunakan teknik meta-analisis. Penelitian ini menggunakan teknik meta-analisis untuk mengintegrasikan 55 data dari 9 jurnal yang mengandung informasi penggantian jagung dengan bahan baku lokal. Teknik meta-analisis diawali dengan pengumpulan data dari beberapa publikasi ilmiah yang mengandung data kadar tanin dan saponin. Selanjutnya data tersebut ditabulasi dalam bentuk database dengan bantuan microsoft excel, dalam proses tabulasi ini satuan dari setiap data disamakan, setelah itu data ditabulasi dan dianalisis menggunakan comprehensive meta-analysis version 3. Pengaruh penggantian jagung pada kualitas daging broiler tidak signifikan, hal ini dapat dilihat pada kandungan persentase karkas, bobot karkas, dan kolesterol daging yang tidak berbeda. Hasil menunjukkan untuk nilai jarak antara model yang diberikan dengan model sebenarnya terdapat indikasi penurunan jumlah kolesterol dalam daging dengan adanya penggantian jagung dalam bahan pakan $(0,05<\mathrm{P}<0,1)$. Kesimpulan dari hasil meta-analisis ini bahwa penggantian jagung tidak meningkatkan kualitas karkas daging broiler.
\end{abstract}

Kata kunci: Daging broiler, Jagung, Kualitas karkas, Meta-analisis, Substitusi

\begin{abstract}
The purpose of this study was to determine the effect of substitution of corn with local ingredients on the quality of broiler meat using meta-analysis technique. This study used meta-analysis technique to integrate 55 data from 9 journals that contain information about replacing corn with local feedstuffs. The meta-analysis technique begins with collecting data from several scientific publications that contain tannin and saponin levels. Furthermore, the data was tabulated in the form of database with the help of microsoft excel, in this tabulation process the units of each data are equalized, after that the data was tabulated and analyzed using comprehensive meta-analysis version 3. The effect of corn replacement on the quality of broiler meat was not significant, this can be seen on the content of the percentage of carcasses, carcass weights, and cholesterol of meat was not different. The results show that the distance between the given model and the actual model indicates that there was decrease in the amount of cholesterol in meat with the replacement of corn in feed ingredients $(0.05<P<0.1)$. The conclusion from the results of this meta-analysis was that the replacement of corn does not improve the quality of the broiler carcass.
\end{abstract}

Keywords: Meat broiler, Corn, Carcass quality, Meta-analysis, Substitution

\section{PENDAHULUAN}

Direktorat Jenderal Peternakan 2019 mencatat pada periode 2015 hingga 2018 rata-rata pertumbuhan produksi daging broiler sebesar 5,58\% dengan tren pertumbuhan kebutuhan sebesar 3,74\%, hal ini diikuti dengan laju pertumbuhan populasi broiler yang cepat yakni $13,22 \%$ per tahun (BPS, 2019).

Pertambahan jumlah penduduk di Indonesia dari tahun ke tahun terus mengalami peningkatan, hal ini akan berdampak pada peningkatan konsumsi 
produk peternakan (daging) yang secara tidak langsung memberikan peluang usaha dalam memajukan industri peternakan Indonesia termasuk perunggasan (Adli et al., 2017). Pakan dalam peternakan menyumbang $70 \%$ dari keseluruhan biaya pemeliharaan (Adli dan Sjofjan, 2018). Upaya efisiensi pakan perlu dilakukan apabila ditinjau dari aspek tersebut. Salah satu upaya adalah mengganti bahan baku pakan utama seperti jagung dan bungkil kedelai dengan bahan baku pakan lokal.

Komponen utama dalam produksi produk peternakan unggas adalah karkas. Karkas merupakan bagian yang dipisahkan dari darah, bulu, kaki, kepala, dan organ dalam kecuali ginjal, jantung, hati dan gizzard (Widiyawati et al., 2020). Meta-analisis merupakan analisis studi statistik dengan cara menganalisis data yang berasal dari studi primer, yang mana hasil analisis studi primer ini digunakan sebagai dasar faktor koreksi, menerima, mendukung dari penelitian yang sudah ada sebelumnya.

Database yang disusun merupakan penelitian terkait baik berupa publikasi yang tersedia pada web jurnal internasional maupun nasional maupun dari penelitian yang belum dipublikasikan, kemudian hasil yang didapatkan dibuat persamaan dengan model matematika sehingga muncul persamaan matematika yang disebut mixed model (Jayanegara et al., 2011). Penelitian ini bertujuan untuk mengetahui pengaruh substitusi jagung dengan bahan pakal lokal terhadap kualitas daging broiler menggunakan teknik meta-analisis.

\section{MATERI DAN METODE}

\section{Materi Penelitian}

Materi yang digunakan dalam penelitian ini adalah hardware komputer, software berupa Microsoft Excel 2013, Microsoft Word 2013, dan program comprehensive metaanalysis version 3. Bahan penelitian yang digunakan yaitu data yang telah dikumpulkan dari beberapa jurnal internasional. Jurnal yang dipilih dalam penelitian ini adalah jurnal yang melaporkan jumlah pengganti jagung yang berpengaruh terhadap kualitas daging, atau jagung sebagai bahan pengganti pada bahan pakan broiler yang dapat maupun tidak meningkatkan kualitas daging broiler. Jumlah jurnal yang digunakan pada penelitian ini terdiri dari 9 jurnal, 9 studi, dan 55 data yang melaporkan pengaruh penggantian jagung terhadap kualitas daging.

Tabel 1. Jurnal Studi Yang Digunakan

\begin{tabular}{|c|c|c|c|c|c|}
\hline No & Referensi & Jenis Bahan pakan & $\begin{array}{c}\text { Jenis } \\
\text { pemberian }\end{array}$ & $\begin{array}{c}\text { Level } \\
\text { penggantian (\%) }\end{array}$ & Strain ayam \\
\hline 1 & Biesek et al. (2020) & Kacang lokal & tepung & $0-15$ & Arbor acres \\
\hline 2 & Dewayani et al. (2015) & $\begin{array}{l}\text { Onggok dan ampas tahu } \\
\text { fermentasi }\end{array}$ & tepung & $0-20$ & Lohmann platinum \\
\hline 3 & Fitro et al. (2015) & Ampas kurma & tepung & $0-7,5$ & Cobb \\
\hline 4 & Garing et al. (2020) & Limbah kulit kopi & tepung & $0-30$ & СР 707 \\
\hline 5 & Natsir et al. (2018) & Palm kernel meal & tepung & $0-37,5$ & CP707 \\
\hline 6 & Osman et al. $(2020)$ & Kacang lokal & tepung & $0-15$ & Arbor acres \\
\hline 7 & Puspitasari et al. (2019) & Bonggol pisang & tepung & $0-10$ & Lohmann MB-202 \\
\hline 8 & Taran et al. (2015) & $\begin{array}{l}\text { Bonggol pisang dan } \\
\text { daun kelor }\end{array}$ & tepung & $0-34$ & Arbor acres CP 707 \\
\hline 9 & Widiyawati et al. (2020) & Biji asam & tepung & $0-100$ & Cobb \\
\hline
\end{tabular}

Data dari berbagai publikasi di atas ditabulasi dalam suatu database berbasis microsoft excel. Pada proses pembuatan database dilakukan persamaan satuan, selanjutnya data diolah dan dikomparasikan dengan metode meta-analisis, dan dibuat permodelan kuantitatif mengenai pengaruh penggantian jagung sebagai substitusi pakan terhadap kualitas daging broiler (Sauvant et al., 2008).

\section{HASIL DAN PEMBAHASAN}

Hasil analisis statistik memberikan pengaruh yang tidak nyata (Tabel 2) terhadap persentase karkas, bobot karkas, dan kolesterol daging. Hal ini menunjukkan bahwa bahan pakan lokal pengganti jagung semakin baik. Semakin tinggi bobot hidup maka semakin meningkatkan produksi karkas. 
Semakin bertambahnya umur ternak, maka sehingga persentase karkas meningkat pertumbuhan ternak semakin bertambah

(Matitaputty et al., 2011).

Tabel 1. Pengaruh Penggantian Jagung Terhadap Kualitas Daging Broiler

\begin{tabular}{lccccccccc}
\hline \multicolumn{1}{c}{ Parameter } & \multirow{2}{*}{ N } & Model & \multirow{2}{*}{ Intercept } & $\begin{array}{c}\text { SE } \\
\text { intercept }\end{array}$ & Slope & $\begin{array}{c}\text { SE } \\
\text { slope }\end{array}$ & $\begin{array}{c}\text { Slope } \\
\text { AIC }\end{array}$ & P intercept \\
\hline Persentase karkas & 55 & Linier & 65,77 & 14,55 & $-0,345$ & 0,855 & 0,765 & 546,66 & 0,0001 \\
Bobot karkas & 55 & Linier & 76,66 & 14,56 & $-0,355$ & 0,765 & 0,566 & 556,66 & 0,0001 \\
Kolesterol daging & 55 & Linier & 78,88 & 13,55 & $-0,566$ & 0,566 & 0,544 & 556,77 & 0,0001 \\
\hline
\end{tabular}

Keterangan: Intercept: Jumlah variabel respon saat bahan pakanpengganti jagung yang diberikan sama dengan nol, SE intercept: standar eror, P intercept: Nilai Peluang intercept, Slope: Nilai kemiringan garis (Gradien), SE slope: Standar eror slope, AIC: Nilai jarak antara model yang diberikan dengan model sebenarnya.

Hasil analisis statistik menunjukkan bahwa intercept pada bobot karkas memiliki nilai terendah yakni 65,77 dibandingkan dengan nilai persentase karkas dan kolesterol daging (Tabel 2). Hal ini diduga adanya faktor lain yaitu metode pengukuran bobot karkas sebagai gambaran dari produksi daging dari seekor ternak. Nilai intercept adalah jumlah variabel respon saat bahan pakan pengganti jagung yang diberikan sama dengan nol.

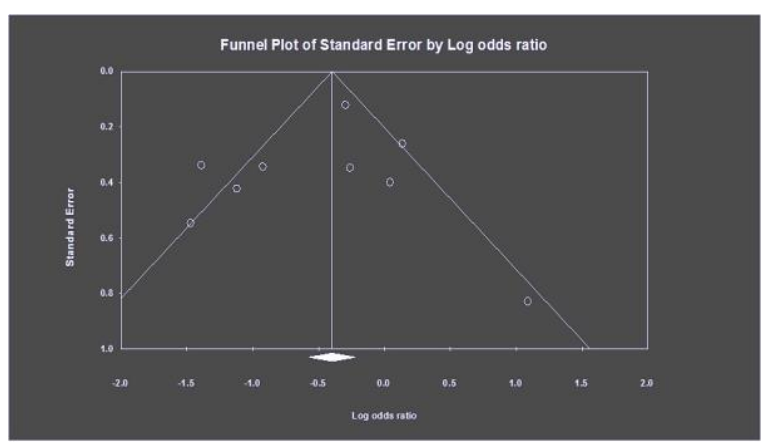

Gambar 1. Standard error pada log odd ratio.

Sementara, pada hasil statistik $S E$ intercept atau standard error (Gambar 1) tidak menunjukkan perbedaan yang nyata. Hal ini menunjukkan bahwa kualitas dari penelitian dan faktor lain seperti faktor eror masih bisa ditoleransi. Menurut Putra et al. (2015) bahwa bobot karkas tidak dipengaruhi oleh jenis kelamin dari ternak sehingga nilai persentase karkas cenderung tidak berbeda nyata.

Semakin banyak penggunakan tepung biji asam fermentasi dalam pakan akan semakin rendah kandungan protein dalam pakan, sehingga kandungan protein menurun tiap perlakuan, karena di dalam kandungan biji asam terdapat zat antinutrisi. Koten
(2010) menyatakan bahwa selain komponen gizi, biji asam fermentasi juga mempunyai kandungan antinutrisi berupa tanin dan tripsin inhibitor. Fungsi dari protein adalah untuk mempertahankan jaringan lama dan mengganti jaringan yang telah rusak sehingga berhubungan langsung dengan pertumbuhan dan perkembangan ayam. Pertumbuhan yang tinggi akan meningkatkan bobot badan dan diikuti dengan peningkatan persentase karkas (Adli et al., 2019a; Adli et al., 2019b).

Hasil analisis statistik menunjukkan bahwa nilai slope tidak memberikan pengaruh nyata pada parameter yang diamati (Tabel 2). Nilai kemiringan garis (slope) pada persentase karkas adalah -0,345 sementara bobot karkas -0,355. Hal ini menunjukkan bahwa presentase karkas erat hubungannya dengan bobot hidup yang diikuti dengan bobot karkas. Menurut Dewanti et al. (2013) persentase karkas sangat berhubungan erat dengan bobot hidup dan bobot karkas ternak. Kondisi ini didukung oleh Imtiyaz et al. (2017) bahwa kualitas karkas dipengaruhi oleh kandungan saponin dan tanin, jika semakin tinggi saponin maka kolesterol dalam daging menurun.

Mekanisme kerja tanin atau saponin dalam menurunkan kolesterol daging dengan menghambat absorpsi kolesterol atau dengan meningkatkan ekresi kolesterol melalui feses. Muharlien et al. (2011) menyatakan bahwa penurunan kadar kolesterol daging pada broiler disebabkan karena adanya kandungan tanin dan minyak atsiri dalam ramuan herbal yang dapat meningkatkan produksi dan sekresi empedu. 
Tanin merupakan salah satu senyawa metabolit sekunder yang dihasilkan oleh tanaman (Sjofjan et al., 2020a). Tanin sebagai anti-nutrisi mampu mengikat protein. Teknologi fermentasi adalah proses penanaman inokulan yang sesuai ke dalam suatu substrat yang dilanjutkan inkubasi pada suhu dan waktu tertentu dengan tujuan terjadinya proses fermentasi yang dapat meningkatkan nilai nutrisi terutama kadar protein (Sjofjan et al., 2020b).

Hasil rata-rata bobot karkas yang tersaji pada Tabel 2 menunjukkan bahwa semakin tinggi nilai AIC (nilai jarak antara model yang diberikan dengan model sebenarnya) pada persentase karkas yaitu 456,66, bobot karkas 556,66, dan kolesterol daging 556,77 maka semakin bagus kualitasnya. Hal ini diduga karena produksi karkas seiring dengan pertambahan bobot hidup. Semakin tinggi bobot hidup, maka semakin tinggi pula bobot karkas yang diperoleh. Produksi karkas erat hubungannya dengan bobot hidup yaitu peningkatan bobot hidup diikuti oleh peningkatan bobot karkas (Londok et al., 2017). Noferdiman (2012) menyatakan bahwa bobot karkas erat kaitannya dengan bobot potong dan pertambahan bobot badan.

\section{KESIMPULAN}

Hasil meta-analisis penggantian jagung dengan penggunaan bahan pakan lokal tidak meningkatkan kualitas karkas daging broiler.

\section{DAFTAR PUSTAKA}

Adli, D.N., O, Sjofjan, and M. Mashudi. 2017. Dried of poultry waste urea-molasses block (DPW-UMB) as potential for feed supplementation. Jurnal Agripet. 17(2): 144-149.

Adli, D. N. and O, Sjofjan. 2018. Nutrient content evaluation of dried poultry waste urea molasses block (DPW-UMB) on in-vitro analysis. Sains Peternakan: Jurnal Penelitian Ilmu Peternakan. 16(2): 50-53.

Adli, D.N., Y. Chi, J.W. Lee, and O. Sjofjan. 2019a. Supplementation mannan-rich fraction (MRF) and/or combination with probiotic-enhanced water acidifier on dietary female broiler at 28 days as natural growth promoters (NGPs). Research Journal of Advanced Engineering and Science. 4(3): 427-429.

Adli, D.N., O. Sjofjan, and M. Mashudi. 2019b. Nutrient content evaluation of dried of poultry waste urea-molasses block (DPW-UMB) on proximate analysis. Jurnal Ilmu dan Teknologi Peternakan. 6(2), 72-76.

Badan Pusat Statistik (BPS). 2019. Populasi Ayam Ras Pedaging Menurut Provinsi 2015-2019.

https://www.bps.go.id/linkTableDinam is/view/id/1034. Diakses 11 November 2019.

Biesek, J., J. Kuźniacka, M. Banaszak, and M. Adamski. 2020. The quality of carcass and meat from broiler fed diets with or without soybean meal. Animals. 10(200): 1-11.

Dewanti, R., M. Irham, dan Sudiyono. 2013. Pengaruh penggunaan enceng gondok terfermentasi dalam ransum terhadap persentase karkas, non-karkas, dan lemak abdominal itik lokal jantan umur delapan minggu. Buletin Peternakan. 37(1): 19-25.

Dewayani, R. E., M.H. Natsir, dan O. Sjofjan. 2017. Pengaruh penggunaan onggok dan ampas tahu terfermentasi mix culture (Aspergillus niger dan Rhizopus oligosporus) sebagai pengganti jagung dalam pakan terhadap kualitas fisik daging ayam pedaging. Jurnal Ilmu dan Teknologi Hasil Ternak (JITEK). 10(1): 9-17.

Fitro, R., E. Dihansih, dan D. Sudrajat. 2015. Performa ayam pedaging yang diberi rasum komersial mengadung ampas kurma sebagai pengganti jagung. Jurnal Peternakan Nusantara. 1(1): 1-8.

Garing, Y., Z. Poli, F.J. Nangoy, and P.R.R.I. Montong. 2020. Pengolahan limbah kulit kopi (Coffea $s p$ ) secara sederhana untuk menggantikan sebagian jagung dan pengaruhnya terhadap kualitas karkas ayam pedaging. Zootec. 40(1): 271-280.

Imtiyaz, S., L.D. Mahfudz, dan D. Sunarti. 2017. Pengaruh penggunaan limbah cair pemindangan ikan dalam ransum 
terhadap kadar lemak daging dan persentase lemak abdominal itik persilangan Mojosari Peking. Jurnal Ilmu-Ilmu Peternakan. 27(3): 63-69.

Jayanegara, A., F. Leiber, and M. Kreuzer. 2012. Meta-analysis of the relationship between dietary tannin level and methane formation in ruminants from in vivo and in vitro experiments. Journal of Animal Physiology and Animal Nutrition. 96(3): 365-375.

Koten, B.B. 2010. Perubahan anti nutrisi pada silase buah semu jambu mete sebagai pakan dengan menggunakan berbagai aras tepung gaplek dan lama pemeraman. Buletin Peternakan. 34(2): 82-85.

Londok, J.J., J.E.G. Rompis, dan C. Mangelep. 2016. Kualitas karkas ayam pedaging yang diberi ransum mengandung limbah sawi. Zootec. 37(1): 1-7.

Matitaputty, P.R., R.R. Noor, P.S. Hardjosworo, dan C.H. Wijaya. 2011. Performa, persentase karkas dan nilai heterosis itik Alabio, Cihateup dan hasil persilangannya pada umur delapan minggu. Jurnal Ilmu Ternak dan Veteriner. 16(2): 90-98.

Muharlien, M., A. Achmanu, dan R. Rachmawati. 2012. Meningkatkan produksi ayam pedaging melalui pengaturan proporsi sekam, pasir dan kapur sebagai litter. Ternak Tropika: Journal of Tropical Animal Production. 12(1): 38-45.

Natsir, M.H., I. Djunaidi, O. Sjofjan, A. Suwanto, E. Puspitasari, and L.J. Virginia. 2018. The effect of corn substitution with palm kernel meal treated by enzyme on production performance and carcass quality of broiler. Buletin Peternakan. 42(2):103-108.

Noferdiman. 2012. Efek penggunaan Azolla microphylla fermentasi sebagai pengganti bungkil kedelai dalam ransum terhadap bobot organ pencernaan ayam broiler. Jurnal Penelitian Universitas Jambi. 4 (1): 4956.

Puspitasari, D.K., O. Sjofjan, dan E. Widodo. 2019. Pengaruh penambahan tepung bonggol pisang pada pakan terhadap berat karkas, persentase karkas, dan lemak abdominal ayam pedaging. Jurnal
Nutrisi Ternak Tropis. 2(1): 33-41.

Putra, A., Rukmiasih dan R. Afnan. 2015. Persentase dan kualitas karkas itik Cihateup-Alabio (CA) pada umur pemotongan yang berbeda. Jurnal Ilmu Produksi dan Teknologi Hasil Peternakan. 3(1): 27-32.

Sauvant, D., P. Schmidely, J.J. Daudin, and N.R. St-Pierre. 2008. Meta-analyses of experimental data in animal nutrition. Animal: An International Journal of Animal Bioscience. 2(8): 1203-1214.

Sjofjan, O., D.N. Adli, P.K. Hanani, dan D. Sulistiyaningru. 2019. The utilization of bay leaf (SyzygiumpolyanthumWalp) Flour in feed on carcass quality, microflora instestine of broiler. International Journal of Engineering Technologies and Management Research. 6(11): 1-9.

Sjofjan, O., M.H. Natsir., D.N. Adli, D.D. Adelina, dan L.M. Triana. 2020a. Effect of symbiotic flour (Lactobacillus Sp. and FOS) to the egg quality and performance of laying hens. IOP Conference Series: Earth and Environmental Science. 465.

Sjofjan, O., D.N. Adli, M.H. Natsir, dan A. Kusumaningtyaswati. 2020b. Pengaruh kombinasi tepung kunyit (Curcuma domestica Val.) dan probiotik terhadap penampilan usus broiler. Jurnal Nutrisi Ternak Tropis dan Ilmu Pakan. 2 (1):1924.

Osman, A., M. Bin-Jumah, M.E. Abd El-Hack, G. Elaraby, A.A. Swelum, A.E. Taha, M. Sitohy, A.A. Allam, and E.A. Ashour. 2020. Dietary supplementation of soybean glycinin can alter the growth, carcass traits, blood biochemical indices, and meat quality of broilers. Poultry Science. 99(2): 820-828.

Taran, S.Y., V.J. Ballo, dan M. Sinlae. 2015. Pengaruh pemberian tepung bonggol pisang dan tepung daun kelor sebagai pengganti jagung terhadap warna, rasa dan keempukan daging ayam broiler. Jurnal Nukleus Peternakan. 2(1): 67-74.

Widiyawati, I., O. Sjofjan, dan D.N. Adli. 2020. Peningkatan kualitas dan persentase karkas broiler dengan subtitusi bungkil kedelai menggunakan tepung biji asam (Tamarindus indica $L$ ) fermentasi. Jurnal Nutrisi Ternak Tropis. 3(1): 35-40. 